Egypt. Acad. J. Biolog. Sci., 5(3): 9-17 (2012)

Email: egyptianacademic@yahoo.com

Received: 15/ 5 /2012
A. Entomology

ISSN: $1687-8809$

www.eajbs.eg.net

\title{
Ecological studies of Aulacaspis tubercularis (Diaspididae: Hemiptera) and its natural enemies infesting mango trees in Sharkia Governorate, Egypt.
}

\author{
Nabil, H. A. ${ }^{\text {; }}$ Shahein, A. A. ${ }^{2}$; Hammad, K.A.A. ${ }^{2}$; and Hassan, A.S. ${ }^{1}$ \\ 1- Plant Protection Research Institute, Agricultural Research Center, Zagazig, Egypt. \\ 2- Plant Protection Department, Faculty of Agriculture, Zagazig Univ., Egypt.
}

\section{ABSTRACT}

Ecological studies of Aulacaspis tubercularis (Newstead) (Diaspididae: Hemiptera) and its natural enemies were carried out during two successive years (2007-2008 and 2008-2009) in Inshas El- Raml district, Sharkia Governorate, Egypt. The obtained results revealed that the total number of alive stages had one peak of activity yearly in both top and bottom levels of the trees. Aphytis sp. and Encarsia sp. (Aphelinidae), Habrolepis diaspidi (Risbec) (Encyrtidae) were recorded as parasitoids of A. tubercularis. Cybocephalus micans Reitter (Order: Nitidulidae) was recorded as predator of A. tubercularis. The total effects of a biotic factors (Temperature ${ }^{\circ} \mathrm{C}$, Relative humidity $\mathrm{RH} \%$ and Light intensity Lux) under this study on the total numbers of alive stages of the pest during the two years were 63.19 and $40.20 \%$ in the top level and 77.66 and $39.44 \%$ in the bottom one, successively. The pest activity appeared three annual generations in either the top and bottom levels of mango trees.

Keywords: Ecological studies, Aulacaspis tubercularis, natural enemies, mango trees, Egypt.

\section{INTRODUCTION}

Mango trees, Mangifera indica L. (Anacardiaceae) considered as one of the most popular fruits in Egypt. It contains a high percent of sugar, protein, fats, salts, vitamins. It plays an important role in food industrialization such as juices, which wanted with large amounts to export according to good reputation of Egyptian varieties. Now, the Egyptian agricultural strategy is to increase the quality level of exported crops to certain European countries, for this reason many efforts has been done to increase the total cultivated areas of mango in Egypt, as a favorable fruits in many countries. The total cultivated areas in Egypt has been rapidly increased and reached about 129073 feddans in 2007, producing a yield of approximately 497771 tons. In Sharkia Governorate, cultivated areas were 20873 feddans producing a yield of approximately 95428 tons. (Economic Agricultural Report, from Central Administration for Economic Agriculture, Ministry of Agriculture, Egypt, 2007).Scale insects are usually considered as the most important pests which infesting mango trees in many countries of the world. Gallardo (1983), Williams and Watson (1988) reported that a heavy infestation of Aulacaspis tubercularis (Newstead) (Diaspididae : Hemiptera) occurred on mango in an experimental orchard containing 84 varieties in Puerto Rico. This scale insect injures the leaves and fruits, affecting the commercial value of the fruits and its export potential. Colyn and Schaffer (1993), Peña et al. (1998) and Joubert et al. (2000) mentioned that A. tubercularis injures the leaves and fruits, affecting the commercial value of the fruits and their export potential. Infested mango fruits have conspicuous pink blemishes around the feeding sites of the scales. In nurseries, severe early-stage infestation retards growth. Young trees are particularly vulnerable

Workshop of Scale Insects and their role in agricultural development in Egypt. Held in Agricultural Research Center, Plant Protection Research Institute, Scale Insects Division 
to excessive leaf loss and death of twigs due to scale, during hot dry weather. A. tubercularis presents significant pest problems on mango in South Africa. It is also a problem on mango in Australia, East and West Africa, North and South America and the Caribbean Islands. Ascher et al. (1995) studied the ecological aspects of this pest on mango trees using data gathered from two localities, Kaapmuiden and Nelspruit, South Africa. They revealed that the highest infestation rate occurred on the shady south-facing lower aspect of the tree. Population peaks of the pest occurred during different periods of the year in the two regions monitored. The population peak at Kaapmuiden, with a higher mean temperature, occurred in August, much earlier than at Nelspruit, where it occurred in November. Radwan (2003) reported that A. tubercularis had three generations on mango trees at Beni- Swief Governorate, Egypt. Kwaiz (2009) in Egypt, mentioned that this insect had three peaks on mango occurred during March, June and November through each of the two studied years, while the lowest population was occurred in mid July. Also, data clearly showed that $A$. tubercularis had four overlapping annual generations during the two studied years.

\section{MATERIALS AND METHODS}

Field experiments were carried out in mango farm located in Inshas El-Raml district, Sharkia Governorate. This study was continued for two successive years, from March 2007 until February 2009. The farm received normal agricultural practices and no chemical control was applied. The study was conducted in an area of about one feddan for mango variety Shmama. Five trees were selected and labeled. These trees were nearly similar in size, age and vegetation. Each tree was divided into four main directions (east, west, north and south).

For sampling, five leaves were picked up at random once a month from each direction, i.e. 200 leaves per sample $(5$ trees $\times 4$ directions $\times 5$ leaves $\times 2$ levels of the tree). The samples were put in polyethylene bags and transferred into the laboratory for carefully inspection. These samples were examined in the same day using a stereomicroscope whereas the different stages of $A$. tubercularis and Immature stages of predator were counted and recorded.

To study the parasitism ratios of $A$. tubercularis, the insects on each sample were separated into healthy alive insects and parasitized ones which bearing emerging holes of parasitoid adults or including parasitoids larvae or pupae. Each healthy alive insects or parasitized ones were counted and recorded. Parasitized scales were preserved in glass jars covered with muslin cloth by the aid of rubber bands and kept under laboratory conditions until parasitoids emergence. The total parasitism percentage for each sample was estimated. All emerging parasitoids were mounted in canada balsam. Parasitoids and predator were identified with helping of Prof. Dr. A. R. Hamed, Chief Researcher emirates, Biological Control Department, Plant Protection Research Institute, Agricultural Research Center, Giza, Egypt.

The prevailing means of air temperature $\left({ }^{\circ} \mathrm{C}\right)$ and relative humidity $(\mathrm{RH} \%)$ in the experimental area during the periods of the present study were obtained from the Central Laboratory for Agricultural Meteorology, Agricultural Research Center, Ministry of Agriculture. Light intensity (Lux) in outer zone of the trees was measured at the sampling days using Luxmeter at mid-day (12 a.m.), when the sunlight was perpendicular with the earth to obtain the highest light intensity. The relationships between the tested climatic factors and each insect population, predator population and parasitism ratios were studied. Simple correlation, partial regression values and explained variance were calculated using COSTAT Computer Program (2005). 
To detect the effect of the cardinal directions on the distribution of scale insects and its associated natural enemies mathematically, the following formula was used.

$$
\mathrm{H}=\sqrt{\mathrm{F}_{1}^{2}+\mathrm{F}_{2}^{2}+2 \mathrm{~F}_{1} \mathrm{~F}_{2} \operatorname{Cos} \mathrm{Q}}
$$

This angle was calculated by dividing $F_{2} / F_{1}$, Mahmoud (1981), Hassan (1998) and Nabil (2003):

$\mathrm{H}=$ Powers summation

$F_{1}=$ The population on the east (E) minus the population on the west (W) if the first is higher and reversed it if the later is higher.

$\mathrm{F}_{2}=$ The population on the north $(\mathrm{N})$ minus the population on the south $(\mathrm{S})$ if the first is higher and the reverse is applied if the population on the south is higher.

The figure obtained represents the tangent, the corresponding values of which was obtained form the mathematical.

$$
\mathrm{F}_{1}=\mathrm{E}-\mathrm{W} \quad \mathrm{F}_{2}=\mathrm{N}-\mathrm{S} \quad \mathrm{Tan} \mathrm{Q}=\mathrm{F}_{2} / \mathrm{F}_{1}
$$

\section{RESULTS AND DISCUSSION}

\section{Seasonal abundance}

\subsection{Total number of alive stages}

As shown from obtained data in Tables (1 and 2) in the top level of mango trees during the two successive years, the total number of alive stages indicated one peak in November with values of 18634 and 40935 individuals during the first and second years, respectively. Generally, the total number of alive stages during the second year (223300 individuals) was obviously higher in comparison with that during the first year (133525 individuals). Data given in Tables (3 and 4) revealed that the total number of alive stages in the bottom level of mango trees showed one peak in November with counts of 24541 and 44777 individuals during the two successive years. In general, the total number of alive stages during the second year (207399 individuals) was clearly higher as compared with that during the first one (143654 individuals).

These results are in agreement with the findings of Ascher et al. (1995) who reported that the population peaks of the pest occurred during different periods of the year, the population peak at Kaapmuiden occurred in August, much earlier than at Nelspruit, where it occurred in November.

\subsection{Percentages of total mortality}

Data presented in Tables (1 and 2) showed that the percentages of total mortality in the top level of mango trees during the two successive years, indicated two peaks. They took place in June and February during the first year and in August and January during the second year, with values of $47.31,75.14,42.45$ and $53.40 \%$, respectively. The mean percentage of total mortality during the first year $(57.68 \%)$ was relatively higher than the mean percentage of total mortality during the second one $(51.58 \%)$. As shown from obtained data in Tables (3 and 4) in the bottom level of mango trees during the first year, the percentages of total mortality had three peaks of mortality in April (55.99\%), December (66.12\%) and February (76.80\%). While, during the second year, two peaks were noticed in August (49.67\%) and October (49.94\%). The mean percentage of total mortality during the first year (56.54\%) was relatively higher as compared with that during the second one (48.02\%). 


\subsection{Predator population}

During the course of this work, Cybocephalus micans Reitter (Order: Nitidulidae) was recorded as predator of $A$. tubercularis for the first time in Egypt.

Table 1: Seasonal abundance of Aulacaspis tubercularis and its natural enemies in the top level of mango trees, variety Shmama, in Inshas El-Raml district, Sharkia Governorate during the first year (2007-2008).

\begin{tabular}{|c|c|c|c|c|c|c|c|c|c|c|c|c|c|}
\hline \multirow{3}{*}{ Month } & \multicolumn{10}{|c|}{ Number of insects / 100 leaves } & \multicolumn{3}{|c|}{$\begin{array}{l}\text { Monthly average of climatic } \\
\text { factors }\end{array}$} \\
\hline & \multicolumn{4}{|c|}{ Alive stages } & \multirow{2}{*}{ 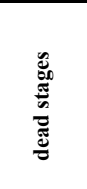 } & \multirow{2}{*}{ 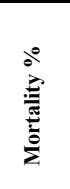 } & \multirow{2}{*}{ 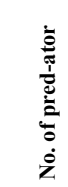 } & \multirow{2}{*}{ 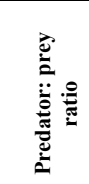 } & \multicolumn{2}{|c|}{ Parasitoids } & \multirow[t]{2}{*}{$\begin{array}{l}\text { Temp. } \\
\left({ }^{\circ} \mathrm{C}\right)\end{array}$} & \multirow[t]{2}{*}{$\begin{array}{l}\text { RH } \\
(\%)\end{array}$} & \multirow[t]{2}{*}{$\begin{array}{c}\text { Light } \\
\text { intensity } \\
\text { (Lux) }\end{array}$} \\
\hline & Females & Males & Nymphs & Total & & & & & No. & $\%$ & & & \\
\hline Mar., 2007 & 1670 & 9560 & 290 & 11520 & 13700 & 54.32 & 31 & $1: 372$ & 488 & 1.93 & 24.7 & 60.7 & 74000 \\
\hline Apr. & 1289 & 7297 & 375 & 8961 & 10561 & 54.10 & 70 & $1: 128$ & 596 & 3.05 & 22.6 & 57.6 & 85000 \\
\hline May & 646 & 4879 & 327 & 5852 & 5013 & 46.14 & 139 & $1: 42$ & 344 & 3.17 & 27.9 & 56.9 & 87000 \\
\hline Jun. & 507 & 3609 & 422 & 4538 & 4075 & 47.31 & 235 & $1: 19$ & 210 & 2.44 & 30.6 & 58.9 & 90000 \\
\hline Jul. & 632 & 4256 & 474 & 5362 & 4377 & 44.94 & 259 & $1: 21$ & 180 & 1.85 & 31.8 & 65.6 & 86000 \\
\hline Aug. & 1044 & 6860 & 732 & 8636 & 6978 & 44.69 & 288 & $1: 30$ & 258 & 1.65 & 31.9 & 67.1 & 85000 \\
\hline Sep. & 2024 & 11003 & 1186 & 14213 & 11719 & 45.19 & 416 & $1: 34$ & 364 & 1.40 & 30.2 & 65.4 & 84000 \\
\hline Oct. & 2868 & 12539 & 1226 & 16633 & 18506 & 52.67 & 289 & $1: 58$ & 628 & 1.79 & 29.0 & 62.2 & 73000 \\
\hline Nov. & 2940 & 14738 & 956 & 18634 & 26817 & 59.00 & 160 & $1: 116$ & 961 & 2.11 & 24.2 & 62.6 & 55000 \\
\hline Dec. & 2139 & 13150 & 594 & 15883 & 26992 & 62.96 & 91 & $1: 175$ & 1050 & 2.45 & 19.2 & 63.2 & 60000 \\
\hline Jan., 2008 & 2058 & 11829 & 395 & 14282 & 26037 & 64.58 & 37 & $1: 386$ & 1130 & 2.80 & 15.6 & 65.2 & 50000 \\
\hline Feb. & 1289 & 7467 & 255 & 9011 & 27243 & 75.14 & 31 & $1: 291$ & 1373 & 3.79 & 17.3 & 65.5 & 60000 \\
\hline Total & 19106 & 107187 & 7232 & 133525 & 182018 & & 2046 & & 7582 & & & & \\
\hline Mean & & & & & & 57.68 & & $1: 65$ & & 2.40 & & & \\
\hline
\end{tabular}

Table (2): Seasonal abundance of Aulacaspis tubercularis and its natural enemies in the top level of mango trees, variety Shmama, in Inshas El-Raml district, Sharkia Governorate during the second year (2008-2009).

\begin{tabular}{|c|c|c|c|c|c|c|c|c|c|c|c|c|c|}
\hline \multirow{3}{*}{ Month } & \multicolumn{10}{|c|}{ Number of insects / 100 leaves } & \multicolumn{3}{|c|}{ Monthly average of climatic factors } \\
\hline & \multicolumn{4}{|c|}{ Alive stages } & \multirow{2}{*}{ 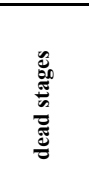 } & \multirow{2}{*}{ 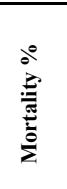 } & \multirow{2}{*}{ 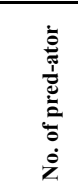 } & \multirow{2}{*}{ 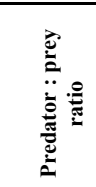 } & \multicolumn{2}{|c|}{ Parasitoids } & \multirow[t]{2}{*}{$\begin{array}{c}\text { Temp. } \\
\left({ }^{\circ} \mathrm{C}\right)\end{array}$} & \multirow[t]{2}{*}{$\begin{array}{l}\text { RH } \\
(\%)\end{array}$} & \multirow[t]{2}{*}{$\begin{array}{c}\text { Light } \\
\text { intensity } \\
\text { (Lux) }\end{array}$} \\
\hline & Females & Males & Nymphs & Total & & & & & No. & $\%$ & & & \\
\hline Mar., 2008 & 1156 & 7266 & 143 & 8565 & 22376 & 72.32 & 55 & $1: 156$ & 1239 & 4.00 & 22.9 & 62.2 & 70000 \\
\hline Apr. & 707 & 5201 & 84 & 5992 & 13995 & 70.02 & 133 & $1: 45$ & 1021 & 5.11 & 27.8 & 56.8 & 87000 \\
\hline May & 470 & 3973 & 39 & 4482 & 8945 & 66.62 & 258 & $1: 17$ & 607 & 4.52 & 27.9 & 65.6 & 86000 \\
\hline Jun. & 536 & 4332 & 66 & 4934 & 4666 & 48.60 & 351 & $1: 14$ & 396 & 4.13 & 32.0 & 58.9 & 90000 \\
\hline Jul. & 661 & 6140 & 156 & 6957 & 5016 & 41.89 & 365 & $1: 19$ & 243 & 2.03 & 32.7 & 66.1 & 91000 \\
\hline Aug. & 1264 & 9252 & 242 & 10758 & 7935 & 42.45 & 556 & $1: 19$ & 247 & 1.32 & 33.5 & 67.7 & 85000 \\
\hline Sep. & 2137 & 17118 & 248 & 19503 & 11541 & 37.18 & 438 & $1: 45$ & 371 & 1.20 & 31.8 & 63.3 & 80000 \\
\hline Oct. & 4581 & 31168 & 410 & 36159 & 27544 & 43.24 & 370 & $1: 98$ & 725 & 1.14 & 27.7 & 63.3 & 72000 \\
\hline Nov. & 4935 & 35485 & 515 & 40935 & 45023 & 52.38 & 200 & $1: 205$ & 987 & 1.15 & 25.0 & 60.0 & 75000 \\
\hline Dec. & 5608 & 29741 & 622 & 35971 & 39786 & 52.52 & 130 & $1: 277$ & 1369 & 1.81 & 20.0 & 61.7 & 70000 \\
\hline Jan., 2009 & 3715 & 20090 & 380 & 24185 & 27710 & 53.40 & 65 & $1: 372$ & 988 & 1.90 & 17.7 & 60.3 & 65000 \\
\hline Feb. & 3888 & 20695 & 276 & 24859 & 23328 & 48.41 & 22 & $1: 1130$ & 597 & 1.24 & 18.9 & 60.8 & 55000 \\
\hline Total & 29658 & 190461 & 3181 & 223300 & 237865 & & 2943 & & 8790 & & & & \\
\hline Mean & & & & & & 51.58 & & $1: 76$ & & 1.91 & & & \\
\hline
\end{tabular}

Data presented in Tables (1 and 2) showed that the highest number of predator in the top level of mango trees during the two successive years was in September (416 individuals) and in August (556 individuals), respectively. The highest ratio of predator: prey was in June, with ratio of 1:19 and 1:14 during the first and second years, respectively. The total number of predator during the second year (2943 individuals) was obviously higher than that recorded during the first one (2046 individuals). The mean ratio of predator: prey during the first year (1:65) was relatively higher in comparative with that during the second one (1:76). 
Data concerning the bottom level of mango trees presented in Tables ( 3 and 4). During the two successive years, the predator number peaked in August with counts of 574 and 446 individuals, respectively. The highest ratio of predator: prey (1:12) during the first year was in July. During the second year, the predator: prey reached the highest ratio (1:15) in June, July and August. The total number of predator during the first year was relatively higher than that during the second one with 3065 and 2598 individuals, consecutively. The mean of predator: prey ratio during the first year (1:47) was higher compared with that during the second one (1:80). These results are in agreement with the findings of Kehat (1967) who reported that the highest density of Cybocephalus beetles in Israel was recorded between May and December.

Table 3: Seasonal abundance of Aulacaspis tubercularis and its natural enemies in the bottom level of mango trees, variety Shmama, in Inshas El-Raml district, Sharkia Governorate during the first year (2007-2008).

\begin{tabular}{|c|c|c|c|c|c|c|c|c|c|c|c|c|c|}
\hline \multirow{3}{*}{ Month } & \multicolumn{10}{|c|}{ Number of insects / 100 leaves } & \multicolumn{3}{|c|}{$\begin{array}{c}\text { Monthly average of climatic fac- } \\
\text { tors }\end{array}$} \\
\hline & \multicolumn{4}{|c|}{ Alive stages } & \multirow{2}{*}{ 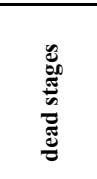 } & \multirow{2}{*}{ 方 } & \multirow{2}{*}{ 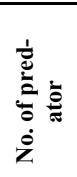 } & \multirow{2}{*}{ 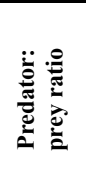 } & \multicolumn{2}{|c|}{ Parasitoids } & \multirow[t]{2}{*}{$\begin{array}{c}\text { Temp. } \\
\left({ }^{\circ} \mathrm{C}\right)\end{array}$} & \multirow[t]{2}{*}{$\begin{array}{l}\text { RH } \\
(\%)\end{array}$} & \multirow[t]{2}{*}{$\begin{array}{c}\text { Light inten- } \\
\text { sity (Lux) }\end{array}$} \\
\hline & Females & Males & Nymphs & Total & & & & & No. & $\%$ & & & \\
\hline Mar., 2007 & 1682 & 9930 & 165 & 11777 & 13225 & 52.90 & 47 & $1: 251$ & 461 & 1.84 & 24.7 & 60.7 & 74000 \\
\hline Apr. & 1339 & 7628 & 269 & 9236 & 11752 & 55.99 & 105 & $1: 88$ & 632 & 3.01 & 22.6 & 57.6 & 85000 \\
\hline May & 736 & 4678 & 328 & 5742 & 4801 & 45.54 & 189 & $1: 30$ & 306 & 2.90 & 27.9 & 56.9 & 87000 \\
\hline Jun. & 567 & 3744 & 267 & 4578 & 3290 & 41.81 & 366 & $1: 13$ & 196 & 2.49 & 30.6 & 58.9 & 90000 \\
\hline Jul. & 777 & 4828 & 224 & 5829 & 2207 & 27.46 & 488 & $1: 12$ & 232 & 2.89 & 31.8 & 65.6 & 86000 \\
\hline Aug. & 1154 & 6115 & 292 & 7561 & 4027 & 34.75 & 574 & $1: 13$ & 280 & 2.42 & 31.9 & 67.1 & 85000 \\
\hline Sep. & 2083 & 9715 & 987 & 12785 & 9654 & 43.02 & 544 & $1: 24$ & 409 & 1.82 & 30.2 & 65.4 & 84000 \\
\hline Oct. & 2502 & 15938 & 1538 & 19978 & 15490 & 43.67 & 412 & $1: 48$ & 639 & 1.80 & 29.0 & 62.2 & 73000 \\
\hline Nov. & 3365 & 20048 & 1128 & 24541 & 30354 & 55.29 & 201 & $1: 122$ & 1030 & 1.88 & 24.2 & 62.6 & 55000 \\
\hline Dec. & 1927 & 13394 & 431 & 15752 & 30737 & 66.12 & 97 & $1: 162$ & 1653 & 3.56 & 19.2 & 63.2 & 60000 \\
\hline Jan., 2008 & 2063 & 13132 & 299 & 15494 & 27002 & 63.54 & 25 & $1: 620$ & 1746 & 4.11 & 15.6 & 65.2 & 50000 \\
\hline Feb. & 1377 & 8810 & 194 & 10381 & 34358 & 76.80 & 17 & $1: 611$ & 1361 & 3.04 & 17.3 & 65.5 & 60000 \\
\hline Total & 19572 & 117960 & 6122 & 143654 & 186897 & & 3065 & & 8945 & & & & \\
\hline Mean & & & & & & 56.54 & & $1: 47$ & & 2.71 & & & \\
\hline
\end{tabular}

Table (4): Seasonal abundance of Aulacaspis tubercularis and its natural enemies in the bottom level of mango trees, variety Shmama, in Inshas El-Raml district, Sharkia Governorate during the second year (2008-2009).

\begin{tabular}{|c|c|c|c|c|c|c|c|c|c|c|c|c|c|}
\hline \multirow{3}{*}{ Month } & \multicolumn{10}{|c|}{ Number of insects / 100 leaves } & \multicolumn{3}{|c|}{ Monthly average of climatic factors } \\
\hline & \multicolumn{4}{|c|}{ Alive stages } & \multirow{2}{*}{ 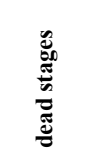 } & \multirow{2}{*}{$\frac{e^{0}}{\sum_{0}^{\circ}}$} & \multirow{2}{*}{ 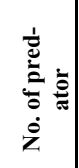 } & \multirow{2}{*}{ 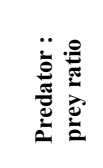 } & \multicolumn{2}{|c|}{ Parasitoids } & \multirow[t]{2}{*}{ Temp. $\left({ }^{\circ} \mathrm{C}\right)$} & \multirow[t]{2}{*}{ RH (\%) } & \multirow[t]{2}{*}{$\begin{array}{l}\text { Light inten- } \\
\text { sity (Lux) }\end{array}$} \\
\hline & Females & Males & Nymphs & Total & & & & & No. & $\%$ & & & \\
\hline Mar., 2008 & 1072 & 6545 & 119 & 7736 & 21000 & 73.08 & 27 & $1: 287$ & 1061 & 3.69 & 22.9 & 62.2 & 70000 \\
\hline Apr. & 611 & 4015 & 92 & 4718 & 10476 & 68.95 & 78 & $1: 60$ & 624 & 4.11 & 27.8 & 56.8 & 87000 \\
\hline Jun. & 444 & 3423 & 93 & 3960 & 3054 & 43.54 & 273 & $1: 15$ & 213 & 3.04 & 32.0 & 58.9 & 90000 \\
\hline Jul. & 570 & 4317 & 125 & 5012 & 3459 & 40.83 & 341 & $1: 15$ & 124 & 1.46 & 32.7 & 66.1 & 91000 \\
\hline Aug. & 846 & 5784 & 150 & 6780 & 6692 & 49.67 & 446 & $1: 15$ & 163 & 1.21 & 33.5 & 67.7 & 85000 \\
\hline Sep. & 2068 & 12643 & 175 & 14886 & 10458 & 41.26 & 348 & $1: 43$ & 304 & 1.20 & 31.8 & 63.3 & 80000 \\
\hline Oct. & 4982 & 23588 & 510 & 29080 & 29014 & 49.94 & 345 & $1: 84$ & 727 & 1.25 & 27.7 & 63.3 & 72000 \\
\hline Nov. & 7926 & 36230 & 621 & 44777 & 37551 & 45.61 & 302 & $1: 148$ & 1253 & 1.52 & 25.0 & 60.0 & 75000 \\
\hline Dec. & 6818 & 28736 & 545 & 36099 & 28018 & 43.70 & 160 & $1: 226$ & 1352 & 2.11 & 20.0 & 61.7 & 70000 \\
\hline Jan., 2009 & 4366 & 23263 & 314 & 27943 & 18269 & 39.53 & 76 & $1: 368$ & 888 & 1.92 & 17.7 & 60.3 & 65000 \\
\hline Feb. & 3020 & 18533 & 181 & 21734 & 19345 & 47.09 & 31 & $1: 701$ & 685 & 1.67 & 18.9 & 60.8 & 55000 \\
\hline Total & 33271 & 171132 & 2996 & 207399 & 191595 & & 2598 & & 7720 & & & & \\
\hline Mean & & & & & & 48.02 & & $1: 80$ & & 1.93 & & & \\
\hline
\end{tabular}

\subsection{Percentages of parasitism}

During the course of this work, four hymenopterous species were recorded as parasitoids of A. tubercularis. They were Aphytis sp. and Encarsia sp. (Aphelinidae), Habrolepis diaspidi (Risbec) (Encyrtidae). The seasonal abundance of the parasitoids 
was presented as percentages of parasitism. Data presented in Tables (1 and 2) showed that in the top level of mango trees during the first year, the percentages of parasitism had one peak of activity in May (3.17\%). During the second year, two peaks were noticed in April (5.11\%) and January (1.90\%). The mean percentages of parasitism were 2.40 and $1.91 \%$ during the first and second years, respectively.

Data given in Tables ( 3 and 4 ) in the bottom level of mango trees during the first year, three peaks were recorded in April (3.01\%), July (2.89\%) and January (4.11\%). While, during the second year, two peaks were noticed in April (4.11\%) and December $(2.11 \%)$. The mean percentages of parasitism were 2.71 and $1.93 \%$ during the first and second years, consecutively. These results are in agreement with the findings of Kamel et al. (2003) who studied the seasonal abundance of 18 species of the genus Aphytis from Egypt, observed on ten host plants infested with eleven armored scale insect species (diaspidids). The maximum parasitism rates were between 0.8 and $14.6 \%$.

\section{Effect of climatic factors:}

\subsection{Total number of alive stages:}

Data given in Table (5) showed that in the top level of mango trees during the two successive years, there were negative significant effects between total number of alive stages and light intensity whereas (r) values were -0.702 and -0.625 , successively. EV\% affected the total number of alive stages by 63.19 and $40.20 \%$ during the first and second years, respectively. Data presented in Table (5) revealed that there was negative highly significant effect between the total number of alive stages and light intensity in the bottom level of mango trees during the first year $(r=-0.736)$. During the second year, there were negative significant correlations between total number of alive stages and each of temperature and light intensity whereas (r) values were -0.585 and -0.616 , respectively. Statistical analysis showed that EV\% affected the total number of alive stages by 77.66 and 39.44 during the first and second years, consecutively.

\subsection{Percentages of total mortality}

Data in Table (5) showed that in the top level of mango trees during the first year, there were negative highly significant effects between percentages of total mortality and each of temperature and light intensity whereas (r) values were -0.917 and 0.845 , successively. During the second year, no significant effects were recorded. EV\% influenced the percentages of total mortality by 87.39 and $46.99 \%$ during the first and second years, respectively. Data given in Table (5) revealed that in the bottom level of mango trees during the first year, there were negative highly significant effects between the percentages of total mortality and each of temperature and light intensity whereas (r) values were -0.939 and -0.753 , respectively. During the second year, no significant effects were noticed. Statistical analysis showed that EV\% affected the percentages of total mortality by 88.68 and $47.57 \%$ during the first and second years, consecutively.

\subsection{Predator population:}

Data given in Table (5) showed that in the top level of mango trees during the first year, there was positive highly significant correlation between numbers of predator and temperature whereas (r) values was 0.820 . While, during the second year, there was positive.

highly significant effect between numbers of predator and temperature $(\mathrm{r}=0.888)$, and positive significant effects between numbers of predator and each of relative humidity and light intensity whereas (r) values were 0.611 and 0.656 , respectively. EV\% af- 
fected numbers of predator by 78.07 and $87.90 \%$ during the first and second years, successively.

As shown from obtained data in Table (5) in the bottom level of mango trees during the two respectively years, there were positive highly significant correlations between numbers of predator and temperature whereas (r) values were 0.885 and 0.777, respectively. Statistical analysis showed that EV\% affected the numbers of predator by 92.46 and $70.72 \%$ during the first and second years, consecutively.

\subsection{Percentages of parasitism:}

Data given in Table (5) revealed that in the top level of mango trees during the first year, there was negative significant effect between percentages of parasitism and temperature $(\mathrm{r}=-0.661)$. While, during the second year, no significant effects were recorded. Statistical analysis showed that EV\% influenced percentages of parasitism by 67.63 and $55.46 \%$ during the first and second years, respectively.

As shown from obtained data in Table (5) in the bottom level of mango trees during the first year, there was negative significant correlation between percentages of parasitism and temperature whereas (r) value was -0.635 . During the second year, no significant effects were recorded. EV\% affected percentages of parasitism by 54.14 and $49.67 \%$ during the first and second years, consecutively.

Table 5: Statistical analysis based on correlation coefficient (r) indicating the effects of climatic factors on different stages of Aulacaspis tubercularis nd its natural enemies on mango trees, variety Shmama, in Inshas El-Raml district, Sharkia Governorate during the two successive years (2007-2008 and 2008-2009).

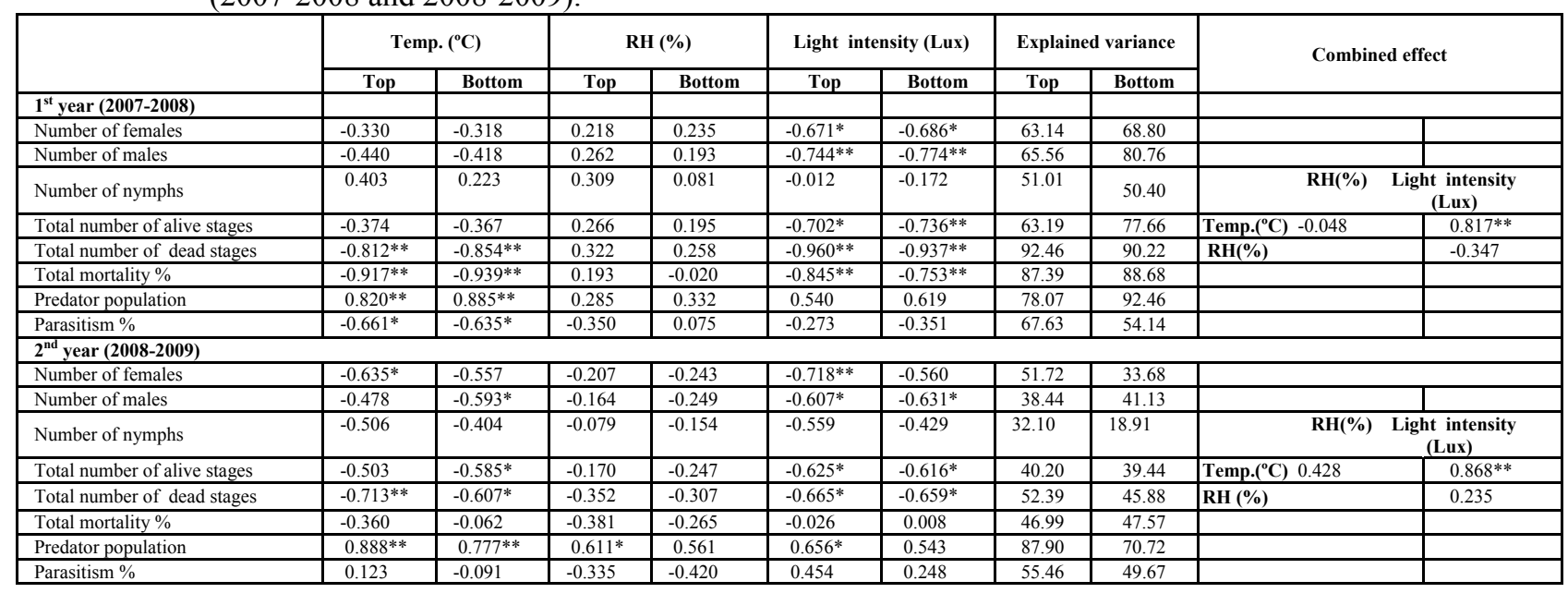

\section{Number of generations:}

As A. tubercularis is known to have overlapping generations, it was necessary to utilize the formula proposed by Audemard and Milaire (1975) and emended by Jacob (1977) for estimating the number of generations and their annual durations. Data of monthly counts of nymphal stage were indicated on millimeter paper.

Data illustrated in Figs. (1 and 2) indicated that during the first year A. tubercularis had three generations annually in the top and bottom levels of mango trees. In General, the generations lasted about three to five months. The first generation was during the period extended from the beginning of March till the end of July. The second and powers one occurred from the beginning of August to the end of October. The third generation occupied the period from the beginning of November till the end of February. While, in the second year, A. tubercularis had three generations annually in the top and bottom levels of mango trees. 


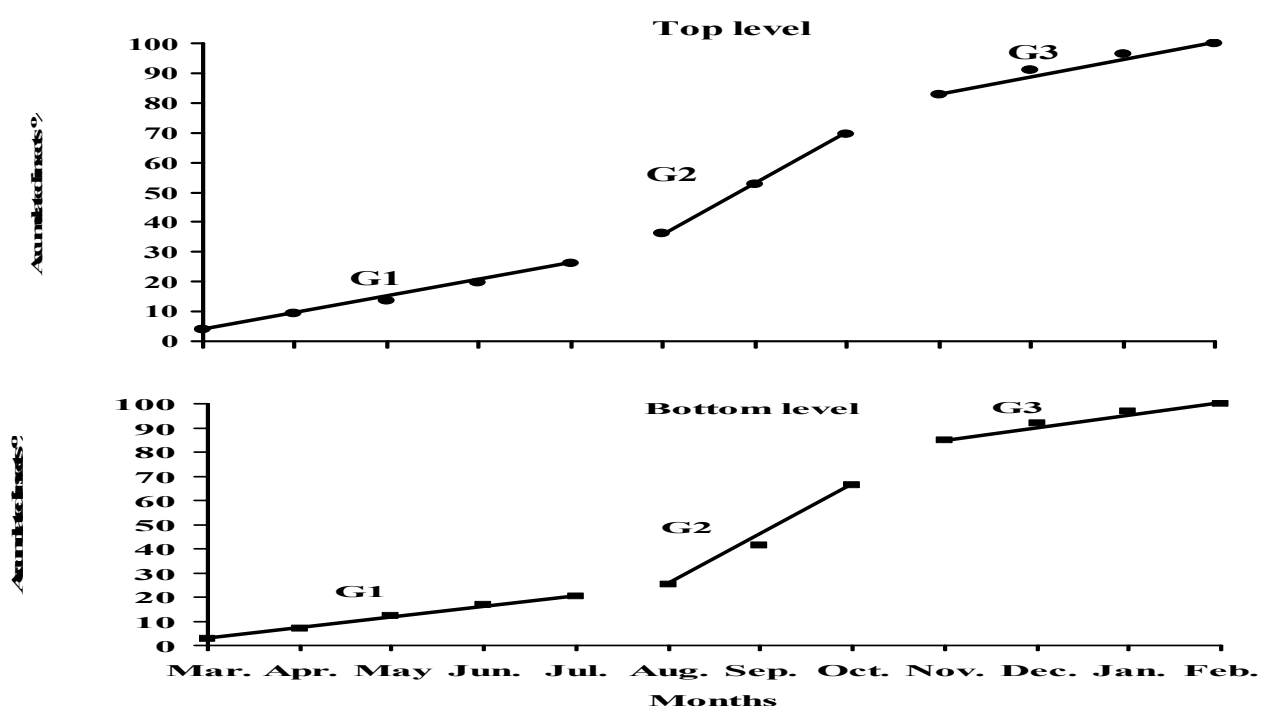

Fig. 1: Annual generations and durations of Aulacaspis tubercularis in top and bottom levels of mango trees, variety Shmama, in Inshas El-Raml district, Sharkia Governorate during the first year (2007-2008).

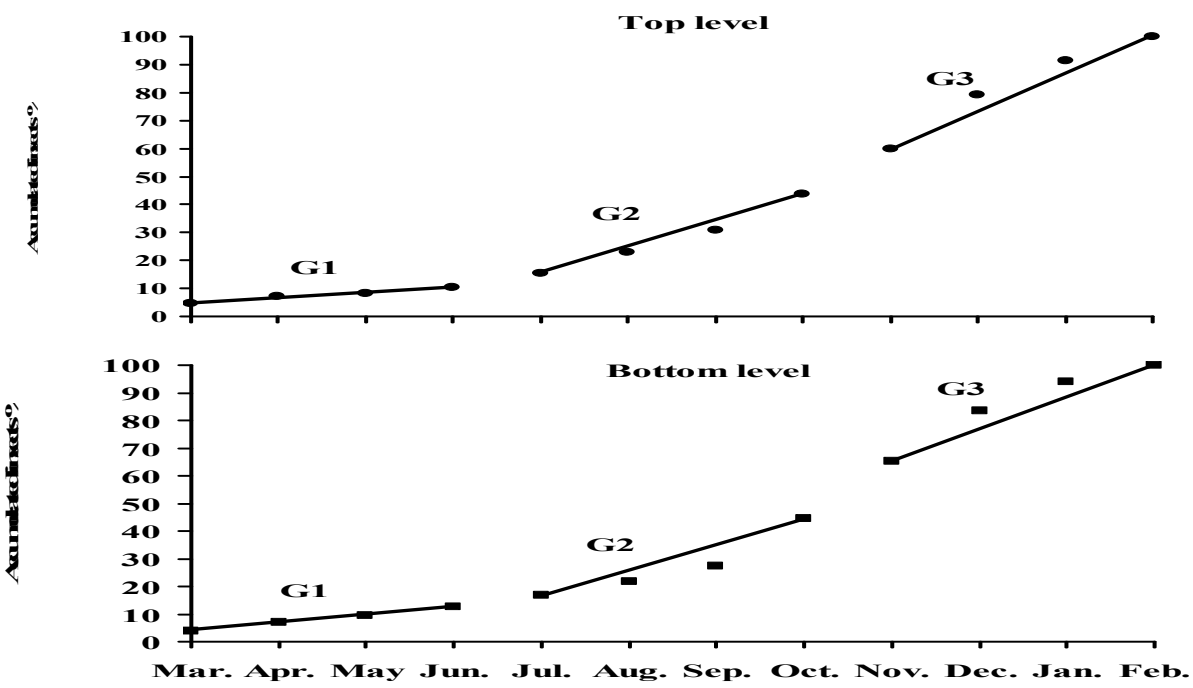

Fig.2: Annual generations and durations of Aulacaspis tubercularis in top and bottom levels of mango trees, variety Shmama, in Inshas El-Raml district, Sharkia Governorate during the first year (2008-2009).

In general, the generations took about four months. The first generation was during the period extended from the beginning of March till the end of June. The second one occurred from the beginning of July to the end of October. The third generation occupied the period from the beginning of November till the end of February. These results are conformable with those of Radwan (2003) who reported that A. tubercularis had three generations on mango trees.

\section{Preferable level and preferable leaf surface}

Data given in Table (6) showed that during the first year, in the top level of mango trees the total number of alive stages, predator and parasitoids were higher on the upper surface of leaves with values of $(80834,1188$ and 5269 individuals) than those on the lower surface with counts of (52691, 858 and 2313 individuals), consecutively. The same trend was found in the bottom level of mango trees whereas the total number of alive stages, predator and parasitoids were 82584, 1852 and 6541 individu- 
als on the upper surface and 61070, 1213 and 2404 individuals on the lower one, respectively.

Table 6: Yearly numbers of Aulacaspis tubercularis and its natural enemies on upper and lower leaves surface for mango trees, variety Shmama, in Inshas El-Raml district, Sharkia Governorate during the first and second years (2007-2008 and 2008-2009).

\begin{tabular}{|c|c|c|c|c|c|c|c|c|c|c|c|c|c|c|c|c|}
\hline \multirow[b]{3}{*}{ Year } & \multicolumn{8}{|c|}{ Top } & \multicolumn{8}{|c|}{ Bottom } \\
\hline & \multicolumn{4}{|c|}{ Upper surface } & \multicolumn{4}{|c|}{ Lower surface } & \multicolumn{4}{|c|}{ Upper surface } & \multicolumn{4}{|c|}{ Lower surface } \\
\hline & 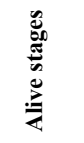 & 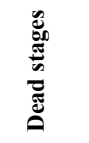 & 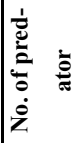 & 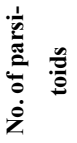 & 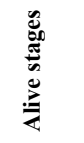 & 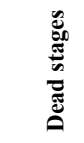 & 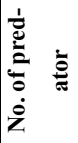 & 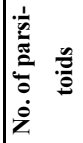 & 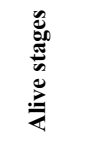 & 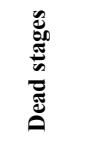 & 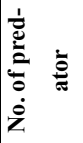 & 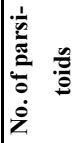 & 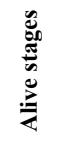 & 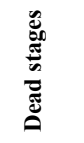 & 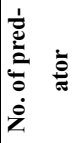 & 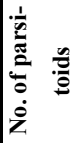 \\
\hline $2007-2008$ & 80834 & 129632 & 1188 & 5269 & 52691 & 52386 & 858 & 2313 & 82584 & 135893 & 1852 & 6541 & 61070 & 51004 & 1213 & 2404 \\
\hline 2008-2009 & 132458 & 148163 & 1845 & 5690 & 90842 & 89702 & 1098 & 3100 & 137743 & 136707 & 1382 & 5282 & 69656 & 54888 & 1216 & 2438 \\
\hline
\end{tabular}

Data given in Table (6) showed that in the top level of mango trees during the second year, the total number of alive stages, predator and parasitoids were obviously higher on the upper surface (132458, 1845 and 5690 individuals) comparatively with those on the lower one (90842, 1098 and 3100 individuals), consecutively. In the bottom level of mango trees the total number of alive stages, predator and parasitoids were $(137743,1382$ and 5282 individuals) on the upper surface and $(69656,1216$ and 2438 individuals) on the lower one, successively.

\section{The preferable direction for the insect and its associated natural enemies}

Results illustrated in Table (7) and Fig. (3) showed that in the top level of the trees during the first and second years, the insect and its predator occurred in north eastern side of the trees. While, the parasitoids occurred in north western side of the trees

Data given in Tables (7) and Fig. (3) revealed that in the bottom level of the trees during the first and second years, the insect and its parasitoids occurred in north eastern side of the trees, whereas the predator occurred in the south eastern side of the trees.

Generally, illustrated data in Fig. (3) revealed that the armored scale insect, $A$. tubercularis and its natural enemies concentrated in eastern side of the trees.

Table (7): Yearly numbers of Aulacaspis tubercularis and its associated natural enemies in the top and bottom levels at main directions of mango trees, variety Shmama, in Inshas El- Raml district, Sharkia Governorate during the first and second years (2007-2008 and 2008-2009).

\begin{tabular}{|c|c|c|c|c|c|c|c|c|c|c|c|c|}
\hline \multirow{4}{*}{ Year } & \multicolumn{12}{|c|}{ Number of insects in the top level / 25 leaves per each direction } \\
\hline & \multicolumn{3}{|c|}{ East } & \multicolumn{3}{|c|}{ West } & \multicolumn{3}{|c|}{ North } & \multicolumn{3}{|c|}{ South } \\
\hline & \multirow{2}{*}{ Alive stages } & Predator & Parasitoids & \multirow{2}{*}{ Alive stages } & Predator & Parasitoids & \multirow{2}{*}{ Alive stages } & Predator & Parasitoids & \multirow{2}{*}{ Alive stages } & Predator & Parasitoids \\
\hline & & Number & Number & & Number & Number & & Number & Number & & Number & Number \\
\hline $2007-2008$ & 33611 & 513 & 1082 & 24900 & 374 & 1778 & 49901 & 753 & 3545 & 25113 & 406 & 1177 \\
\hline \multirow[t]{2}{*}{ 2008-2009 } & 90726 & 850 & 2090 & 34852 & 554 & 2223 & 58280 & 814 & 3127 & 39442 & 725 & 1350 \\
\hline & \multicolumn{12}{|c|}{ Number of insects in the bottom level / 25 leaves per each direction } \\
\hline \multirow[b]{2}{*}{ Year } & \multirow[b]{2}{*}{ Alive stages } & Predator & Parasitoids & \multirow[b]{2}{*}{ Alive stages } & Predator & Parasitoids & \multirow[b]{2}{*}{ Alive stages } & Predator & Parasitoids & \multirow[b]{2}{*}{ Alive stages } & Predator & Parasitoids \\
\hline & & Number & Number & & Number & Number & & Number & Number & & Number & Number \\
\hline $2007-2008$ & 38394 & 711 & 2477 & 30536 & 659 & 2161 & 51278 & 774 & 3175 & 23446 & 921 & 1132 \\
\hline 2008-2009 & 60925 & 539 & 2018 & 51079 & 428 & 1956 & 51220 & 599 & 2560 & 44175 & 1032 & 1186 \\
\hline
\end{tabular}




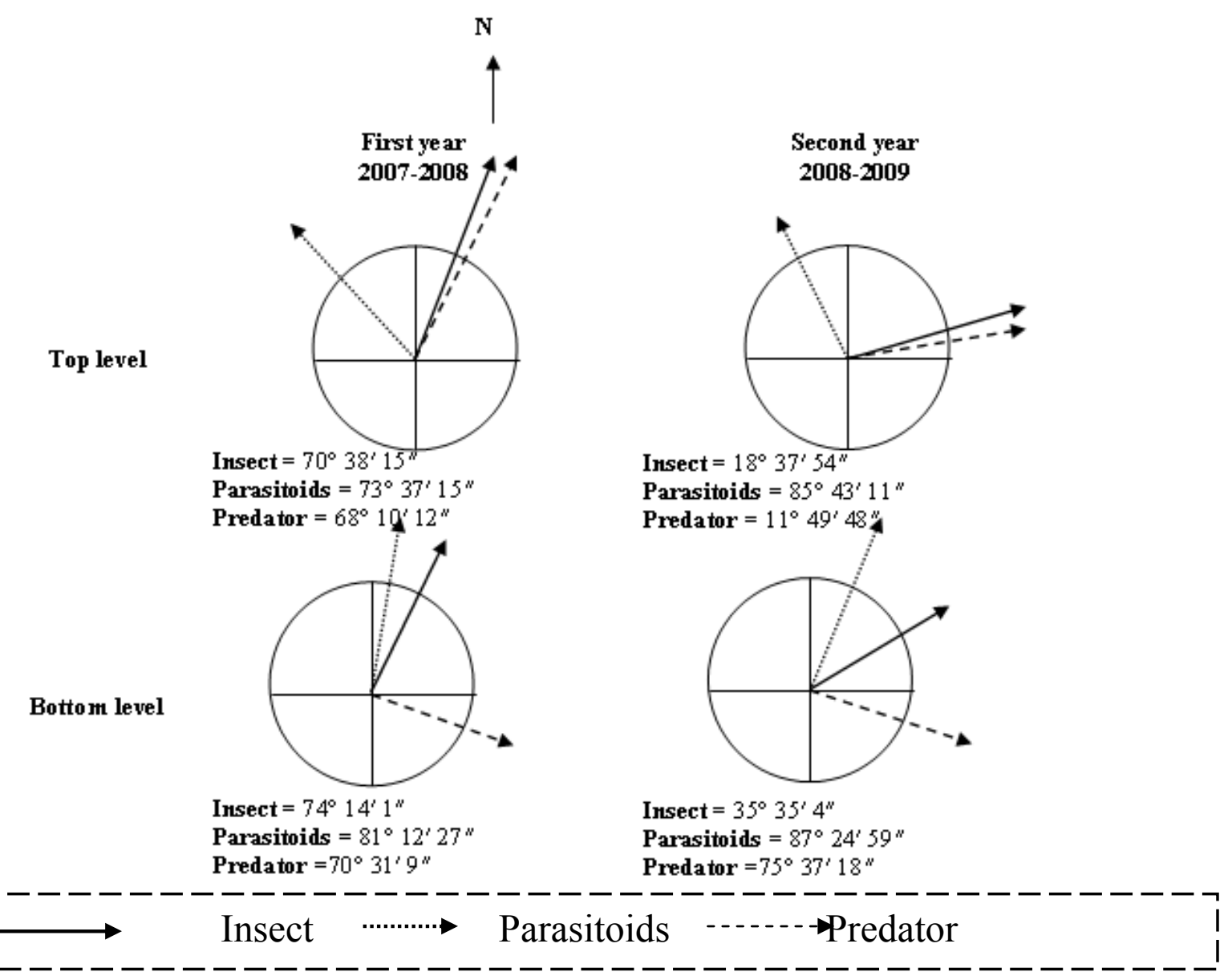

Fig. 3: The calculated directions of Aulacaspis tubercularis and its associated natural enemies in top and bottom levels of mango trees, variety Shmama, in Inshas El-Raml district, Sharkia Governorate tow successive years (2007-2008 and 2008-2009).

\section{REFERENCES}

Ascher, K. R. S.; Ben-Dov, Y.; Labuschagne, T. I.; Van Hamburg, H. and Froneman, I. J. (1995): Population dynamics of the mango scale, Aulacaspis tubercularis (Newstead) (Coccoidea: Diaspididae), in South Africa. Israel J. Entomol., 29: 207-217.

Audemard, H. and Milaire, H. G. (1975): Le pieeage carpocapse (Laspeyresia pomonella L.) avec une pheromone sexuelle de synthese: premiers resultats utilisables pour 1 estimation des populations et laconduite de la lutte. Ann. Zoll. Ecol. Anim.,: 7 - 61 .

Colyn, J. and Schaffer, B. (1993): The South African mango industry. Fourth International Mango Symposium, Miami, Florida, USA. Acta Horticulture, 341: 60-68.

COSTAT (2005): Version 6.311, Copyright(c), CoHort Software, 798 Lighthouse Ave. PMB 320, Monterey, CA, 93940, USA.

Economic Agricultural Report (2007): Central Administration for Agricultural Economic, Ministry of Agriculture, Egypt.

Gallardo, C. F. (1983): Mangoes (Mangifera indica L.) susceptibility to Aulacaspis tubercularis Newstead (Homoptera: Diaspididae) in Puerto Rico. J. Agric. Univ. Puerto Rico., 67 (2): 179. 
Hassan, A. Sh. (1998): Studies on some scale insects and mealybugs infesting certain horticulture crops in newly reclaimed areas. Ph.D. Thesis, Fac. Agric., Zagazig Univ., Egypt.

Jacob, N. (1977): Un model matematic pentru stabilirea. Limitelor economice de toloranta a atacului molilor. Fructelor in Iupte integrate. Analele I. C. P. P., Romania, 15: 179.

Joubert, P. H.; Daneel, M. S.; Grove, T. and Pichakum, A. (2000): Progress towards integrated pest management (IPM) on mangoes in South Africa. Acta Horticulturae, 509: 811-817.

Kamel, A.; Abd-Rabou, S.; Hilmy, N.; Allam, S. and Moustafa, M. (2003): Seasonal abundance of certain Aphytis species (Hymenoptera: Aphelinidae) from Egypt. Egypt. J. Agric. Res., 81 (3): 1009-1023.

Kehat, M. (1967): Survey and distribution of common lady beetles (Col.: Coccinellidae) on date palm trees in Israel. Entomophaga, 12 (2):119-I25.

Kwaiz, Fayza, A. (2009): Ecological studies on the mango scale insect, Aulacaspis tubercularis (Newstead) (Homoptera: Diaspididae) infesting mango trees under field conditions at Qualubia Governorate. Egypt. J. Agric. Res., 87 (1):71-83.

Mahmoud, S. F. (1981): Ecological studies on the California red scale and the purple scale insect on citrus trees and the effect of some recent insecticides on them and their parasites. M.Sc. Thesis, Fac. Agric., Cairo Univ.

Nabil, H. A. (2003): Studies on some species of mealybugs and scale insects infesting guava trees in Sharkia Governorate. M.Sc. Thesis, Fac. Agric., Zagazig Univ.

Peña, J. E.; Mohyuddin, A. I. and Wysoki, M. (1998): A review of the pest management situation in mango agroecosystems. Phytoparasitica, 26 (2):1-20.

Radwan, S. G. A. (2003): Toxicological studies on some scale insects infesting mango and guava trees. Ph.D. Thesis, Fac. Agric., Cairo Univ.

Williams, D. J. and Watson, G. W. (1988): The scale insects of the tropical South Pacific region. Part 1: The armoured scales (Diaspididae). CAB International, Wallingford, UK.

\section{ARABIC SUMMARY}

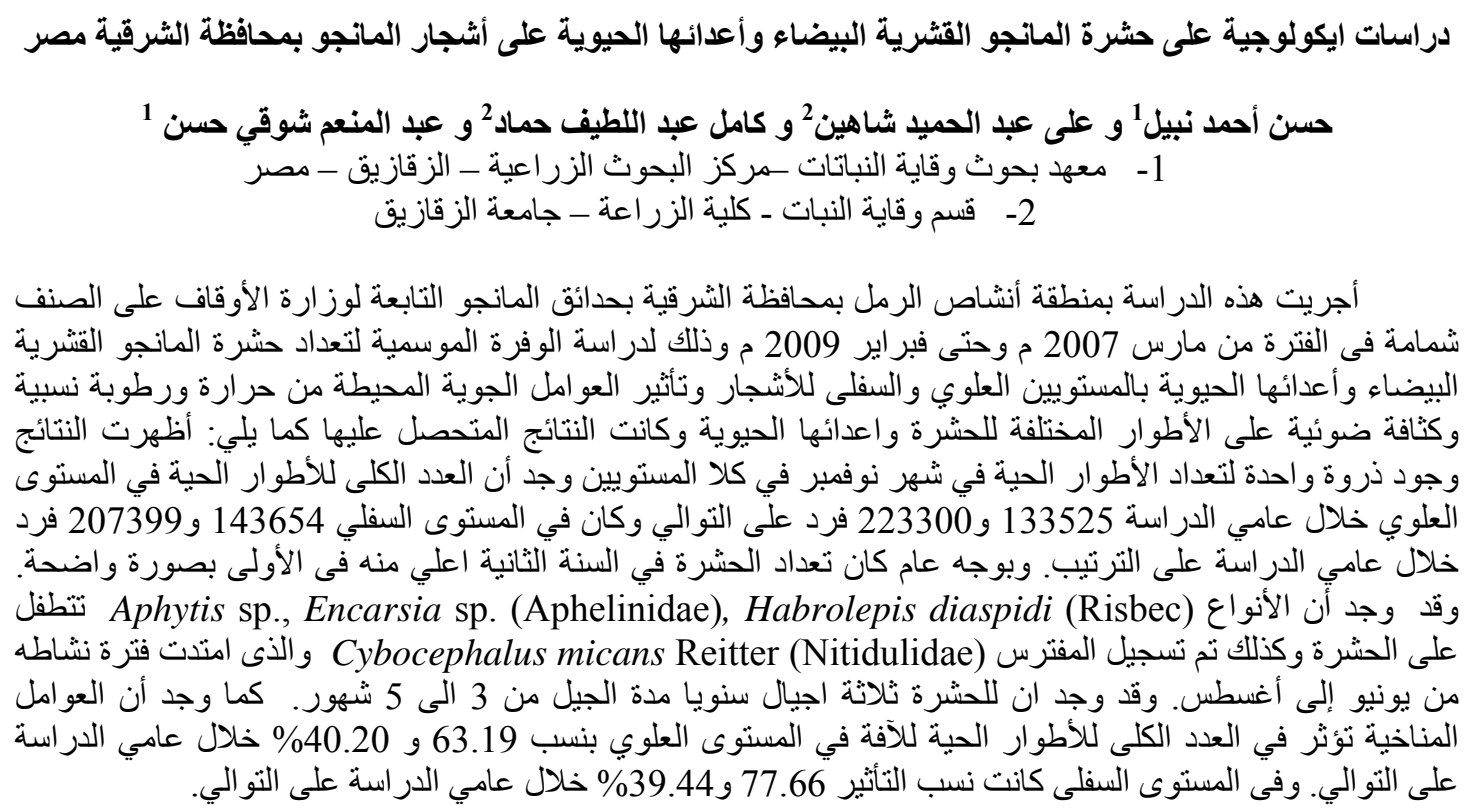

